\title{
Gendered labour regimes: on the organizing of domestic workers in urban China
}

\author{
Xin Tong
}

Correspondence:

tongxin15avril2018@gmail.com Center for the Chinese Workers, Peking University, Wei Xue Yuan 17-313, Beijing 100871, China

\begin{abstract}
The development of China domestic services sector relies on a gendered labour regime that is also at the basis of the country rapid economic growth. Domestic workers face many obstacles at defending their rights. The state's Labour Contract Law does not consider them. Besides, market competition and urban mainstream culture place domestic workers in marginal and atomized positions. But their gender identity, as well as their migrant workers'identity, have become useful resources for the establishment of social support relationships. The networks build on this double identity procure them the emotional support they need and contribute to improve their ability.
\end{abstract}

Keywords: China, Labour, Domestic workers, Gendered regime of production, NGO, Labour union

\section{Domestic service Sector's growth in the contemporary economy in China}

Large percentages of domestic workers are employed under informal conditions in most of the world. I choose to focus on the sector for two sets of reasons. First, it is an expanding sector of the Chinese economy in the context of its rapid growth, in relation with the development of urban middle-class. Domestic workers provide personalized cherished services within homes. The sector represent an increasingly accepted reality that informal work is part of modern economies, and are not simply legacies of the past. This informal sector has begun to organize using alternative strategies. The sector often comprises female migrant workers from rural areas. Based on the gender labour regime, class and the relationship between the urban and rural, female domestic workers become the most vulnerable labourers in Chinese society. Secondly, domestic work tends to be gendered female, often individual and isolated, takes place in the private space; these factors hinder their organizing. Domestic work tends to be conducted on a self-employed basis, it is important the sector that enable us to study important factors influencing their structures and organization efforts. Unions in domestic work are, for the most part, relatively new, and have a spotty presence around the world.

These services mainly include childcare, elder care, cleaning, cooking and other such work traditionally carried out by females. Currently marketized domestic work consists mainly of two types. One is hourly work, in which domestic services are provided on an hourly basis. The second type consists of domestic helpers who live in the employer's home to provide services. The author holds that the infiltration into modern

(c) The Author(s). 2018 Open Access This article is distributed under the terms of the Creative Commons Attribution 4.0 International License (http://creativecommons.org/licenses/by/4.0/), which permits unrestricted use, distribution, and reproduction in any medium, provided you give appropriate credit to the original author(s) and the source, provide a link to the Creative Commons license, and indicate if changes were made. 
society of the ideology and cultural hegemony of gender inequality has resulted in humanity once again producing a gendered labour regime in the service sector.

From approximately 2005 onward, with the conclusion of comprehensive reform of State enterprises, the domestic services industry rapidly developed in the urban areas. In Beijing, for example, there were approximately 230,000 domestic workers in 2006, among whom 40,000 to 50,000 were hourly workers. In 2007, live-in domestic workers exceeded 300,000, and in 2010 there were more than 400,000 domestic workers. In 2010, there were nearly 3,000 domestic services enterprises with industrial and commercial registrations, roughly divided into nine main categories providing nearly 100 types of service involving home cleaning, home cooking, home-based care, home decoration and repair, etc. The People's Republic of China (PRC) (Ministry of Commerce 2015) Domestic Services Industry Development Report states that in 2013, 18 million people were engaged in the domestic services industry, with 600,000 domestic services enterprises (Ministry of Commerce 2015). In 2014, the number of people employed in the domestic services industry rose to 20.34 million, an increase of $13 \%$ over the year before. The increase was 7.2 percentage points higher than the increase in the overall tertiary (service) sector. Among these domestic workers, 58.3\% were employed in sub-scale enterprises. In 2014, domestic services enterprises took in revenues totalling 240 billion Yuan, an increase of 20\%. Calculations indicate that in 2014, profits in the domestic services industry totalled 17.3 billion Yuan, an increase of $11.3 \%$. The annual production value of China's domestic services market is expected to reach 2 trillion Yuan in 2016 or 2017 (Ministry of Commerce 2015). In 2012, according to statistics from the China Home Service Association, China had 24.77 million domestic workers, and in 2011, the domestic services industry's annual production value was nearly 836.6 billion Yuan, comprising 1.77\% of GDP (Gross Domestic Product). ${ }^{1}$ The author estimates that at least 25 million domestic workers of various types are currently employed in China's cities and towns.

Scholars have launched several sociological analytical frameworks on the booming domestic sector. One of frameworks argued that the neoliberal ideology under globalization is considered to have created a huge gap between domestic workers and employers. Global production chain of the global spread of neoliberalism has intensified the commercialization of housework (Ehrenreich and Hochschild 2003). On the one hand, working women face the predicament of the "second shift" after returning home from work (Hochschild 1989). On the other hand, working women in developed countries solve their own reproductive needs by hiring female domestic workers from developing countries, giving rise to the "international division of reproductive labour" of the "global housekeeper chain" (Salazar 2001) which is also an exploitation of maternal labour (Hochschild 2000). The economic inequality between countries involves differences in material living conditions as well as differences in the quality of child and elder care. As "transnational Cinderellas," domestic workers from the Philippines are trapped between liberation and oppression (Lan 2006). The situation in China seems to be more complicated, laying the foundation for rural women as a well as "low-quality" (di suzhi) workforce in the context of urban-rural differences. Yan Hairong discuses that most professionals and other elites who paid domestic workers want to maintain their sense of class superiority; on the other hand, they recognize social mobility, and enlightened employers recognize that "good" employment relationships need to train 
domestic workers' subjectivity (Yan 2010). Others argue the culture and gender ideology is more effective. The media shap the morality and the cultural politic of boundaries in the domestic employment relationship (Sun 2009). Fen Xiaoshuang debate that domestic work takes place in the private sphere, and the rules of emotion and private life play an important role (Feng 2004). The part time work is an employment relationship, but the live-in-home domestic workers is a kind of "similar family member relations" (Zhou and Zhou 2007). In fact, the class consciousness of domestic workers, who are atomized, working and living in the same premises, is vague (Ma 2012). Analysis of media and cultural products, consumer behaviour and everyday politics has discovered that the domestic worker's social status is related to their lack of ability to make their voices heard. The employer's power is reflected not only in the superiority of his or her social, economic and material life, but even more in the employer's monopolization of rights to speak, cultural codes and symbols. Domestic helpers suffer discrimination in the cultural sense, and they can only contend for rights, self-respect and subjectivity through material and cultural consumption (Sun 2009). The third framework is gendered labour regime in the workshops. Indicating that the South China Miracle was founded amidst gendered regimes of production (Lee 1998). Post-modern labour politics should have a gender perspective (Ong 1991). The development of the service industry in transitional China is also gendered labour regime (He 2009). Traditional domestic service work complies with a gendered division of labour, being carried out by females within the home. Modern domestic service work still consists of females providing services through the marketplace. China's economic transformation is a gendered social transformation that has produced a gendered social structure (Song 2015). Rural female workers in the factory system continue to face the triple pressures of state socialism, multinational capitalism and domestic paternalism (Pun 2011). Domestic workers are not only affected by society's expectations and role assignment toward females, but also suffer sexual harassment due to their gender identity (Han 2006). The gendered labour regime under the market system artificially separates the production labour from the care labour, and assigns the care labour to the women. The feminization of the micro care labour constitutes the macroeconomic growth in China (Tong 2017). The forth framework is institution perspective, holds that it is necessary to establish a legal system to protect the rights and interests of workers. It is therefore necessary to establish domestic worker unions and to empower this group through the organization of domestic workers. Only by building labour unions is it possible to help these female domestic workers realize their right to organize while working in the private sphere (Guo 2009).

Some scholars have also noted the emergence of solidarity and resistance, with the spread of informal employment and the flooding of the low-level service industries by migrant labour giving rise to a new form of labour movement. Just as labour unions are going into decline, new forms of labour organizations are emerging in society to organize these informal workers (Milkman 2006). Intellectuals are also joining in the pursuit of social justice (Milkman et al. 2010). However, there are few studies on the solidarities and resistances of domestic workers in China.

I focuse on the organizing of domestic workers. There are three factors that influence the organizing of domestic workers: state, market competition and citizenship. The research focuses on: First, the State's role in the organizing of domestic workers, that is, 
in the process of marketization, how the State converts organized housework in the former work unit (danwei) into individualized informal labour within the family. Second, how does the market weaken the organizing of domestic workers, how the market demand of domestic workers is flexible and the fragmentation of domestic workers. Third, the strength and practice of the organizing of domestic workers, showing the development of various organizations of domestic workers and dynamic of organizating.

Since 2010, I and my research group have studied the domestic service sector using participant observation in a total of seven organizations; including two domestic service companies, a O2O domestic service company, three labour NGOs, a domestic worker's union, and a domestic service.

\section{State: From the socialization of housework under the danwei in the planned economy to the privatization of housework under the market economy}

The development of the domestic sector is embedded in the reforming of the danwei in the planned economy era. Danwei were organized like families, providing food, nurseries, childcare, elder care and other services. An individual's reproduction obtained low-level, extensively coveraged servicing from the work unit system in what was a compensatory paternalistic welfare system. Sons and daughters could even take over the jobs of their parents. The relationship between state-owned enterprises (SOEs) and their workers was like one between parents and children (Tian and Li 2014). Following the SOE reforms that began around 1995, service functions within the danwei were come back to home. The gender order within the home shifted from that of state patriarchy in the planned economy era to the emphasize femininity and virtue of the marketization era. Women fell into three roles: single lady, full-time wife, and dual-income household (Fang 2008). In 1995, sociologies argued on "should working women go home?". 2

First of all, at the outset of Reform and Opening, most families dealt with their reproductive needs within the family. The care of elderly family members might be handled through the formation of a "semi-marketized" setup in which younger family members all contributing to paying for a family member or tangential family member to take on the caretaker role in order to resolve the issue of trust. Very quickly, women who needed to deal with both work and family used women's federations to find a route to commercialized domestic labour.

After the danwei freed family-related services, the Women federation quickly took over the job and actively organized market-oriented domestic services. The Women Domestic Services Centre (Sanba jiazheng fuwu zhongxin) was established in Beijing in 1983, becoming China first domestic services centre. ${ }^{3}$ It assumed two functions. It was finding domestic services for urban families, and it was finding work in the cities for women from impoverished regions. More than 200,000 rural women from impoverished regions have come to Beijing through Women's Federations to work, providing caretaker services to more than 600,000 families since 1983. ${ }^{4}$ The Women Domestic Services Centre plays the role of intermediary and bridge. It has a cooperative relationship with local women's federations, which are responsible for finding women who need to leave their localities to work. The company and the family requiring domestic services sign an introduction contract, and the domestic worker is recommended to the client family as a commercial product. The client family pays an intermediary's fee, 
and if the worker is considered unsuitable, the family can send the worker back to the organization, which will make a total of three introductions. Domestic workers have an intermediary relationship with the company; they have no labour contract, health insurance, retirement benefits, workers' compensation or other social security, and can easily be dismissed from their jobs.

"Women responsible for housework and caretaking work" has indisputably become a collective choice, it's just that these women might be mothers, wives, daughters or any other women willing to take on this kind of work. Women have been collectively selected to become domestic workers. A domestic services market, aimed at satisfying women's housekeeping and child and elder-care needs and comprised mainly of women, was engendered in this way, and amidst the transition to market economy, this profession, from its inception, had an "otherness" that presented itself in irregular labour, market vulnerability and marginalized social status. As a government-like organization, the Women's Federation has actively built a housework market to meet the needs of urban working women. It has the cultural discrimination of urban woman superior to rural woman. The demand side of the urban woman has stronger psychological superiority and negotiation ability. As the organizer of migrant domestic workers, the Women's Federation has not united those workers to protect their rights but meets the demand of urban's woman, and advocated for rural women to bring jobs.

Secondly, The Labour Contract Law in China excludes domestic workers. Up until around the year 2000, China's domestic services market existed without government oversight. ${ }^{5}$ It wasn't until 2001 that the government acknowledged the work of domestic workers and classified it as a bona fide occupation. In 2006, the Ministry of Labour and Social Security promulgated the "National Professional Standards for Domestic Service Workers". The Msinistry divided domestic workers into primary class (state professional qualifications fifth class), intermediary class (fourth class) and high class (third class). According to this standard, "domestic service worker" refers to "a person who according to requirements of the served family manages household chores, takes care of children, the elderly or the sick, and manages matters connected with the household". Localities one after another established household services associations with the objective of "strengthening the professional self-discipline, standardizing professional behaviour, protecting the rights and interests of enterprises and enhancing the standards of the domestic services industry". Some provinces and cities produced professional codes of practice, service quality standards, model contracts and other institutional documents. But these model contracts were mainly for intermediaries. The government appointed the Ministry of Commerce and the Ministry of Human Resources and Social Security as the supervisory units for the industry, as well as coordinating and supporting staff training and energetically promoting the establishment of key enterprises.

The Labour Contract Law promulgated in 2008 does not include domestic workers. The Labour Contract Law concerns contractual relationship between "employer units" and "labourers" but the relationship between households and domestic workers is not a labour relation in that sense. On June 8, 2009, the Ministry of Commerce, the Ministry of Finance and the All-China Federation of Trade Unions jointly issued the "Notice Regarding the Implementation of the 'Domestic Services Project"' in which the domestic services industry became a "project" energetically pushed by the government, i.e., 
"Implementing the domestic services project, utilizing financial and capital support to launch training, supply and demand linkage, employment insurance, etc. for domestic service personnel, and aiding rural migrant workers and laid-off and unemployed individuals in the cities and townships to engage in domestic services" (emphasis added here and below by the author).

On July 29, 2010, the Ministry of Finance and the Ministry of Commerce jointly issued the "Notice Regarding Issues Related to Organizing and Declaring the Domestic Services Industry and the Systemic Construction Project, etc." which decided to launch pilot projects for constructing an urban domestic services system in some cities, including the two tasks of building domestic services network centres and supporting key enterprises. On September 26 of that year, the General Office of the State Council handed down "Guiding Opinions Regarding Developing the Domestic Services Industry", which stated the principle of persisting with a combination of market operation and government guidance. It stated explicitly that domestic services was a focal development industry (zhongdian fazhan yetai), and encouraged all kinds of people to seek and create employment in the domestic services industry and support the expansion and bolstering of domestic services enterprises. In 2012, the "Notice Regarding Issues Related to the 2012 Launch of Constructing the Domestic Services System" continued the push to launch domestic services pilot projects in some cities and supported the training of domestic services personnel.

In January 2015, eight official units, including the Ministry of Human Resources and Social Security and the National Development and Reform Commission, issued the "Notice Regarding the Launch of Building the Domestic Services Industry as a Standardized Profession" (Ministry of Human Resources and Social Security Document No. 98 [2014]), which required that "the domestic services industry standardizing its services, and domestic services personnel professionalizing, is important foundational work for ensuring the provision of domestic services, enhancing the quality of domestic services and promoting the healthy development of the domestic services industry".

On April 22, 2016, the General Office of the State Council issued an opinion regarding implementation of the "Internet + circulation" action plan (State Council General Office Document No. 24 [2016]), which treated domestic services as a sunrise industry, and combined it with Internet to promote it as a new service industry undergoing standardization and playing the role of a new economic driver. The city of Beijing supported pilot enterprises in implementing chain operations and franchise operations, and in accordance with the requirement to construct a national domestic services system, provided preferential funding of up to $50 \%$ of total investment in investment and construction projects of the pilot enterprises - for example remodelling shop space, purchasing related equipment, developing information systems, etc. - in order to alleviate cost pressures on new enterprises.

The domestic sector became a government-led industry, and many domestic service companies were established. Here, the state demonstrates the characteristics of market paternalism, i.e., using market methods to develop the domestic services industry. First, it used the "government project" method to express support for developing the urban domestic services industry, and invested in and promoted the development of domestic services companies and the training of domestic workers. Second, with the needs of urban households coming first, it emphasized the needs of households over labour 
supply. This was manifested in mainly training domestic workers in their domestic abilities. The needs of domestic workers in terms of retirement benefits, medical treatment and workers' compensation were set aside. Although the government encouraged domestic services companies to provide commercial insurance for their workers, it also acknowledged that business interests made this difficult to do. Third, the government directly entered the domestic services industry in the form of purchasing services, as in the case of some local governments purchasing specialized services on an hourly basis for particular families with incapacitated or semi-incapacitated members or particular families who had taken part in family planning and had parents aged 65 or older. Fourth, the government encouraged women's federations, trade unions, Communist Youth Leagues, etc., to organize and establish schools for training domestic workers. Referring to state market paternalism is to underline that all of the above are built on the foundation of a classed gender ideology, i.e., that women's natural instinct is to look after others, that it is not of value, and that providing laid-off female workers and rural women with training and job opportunities was the best development for them. This gender ideology suffuses all aspects of government policy relating to the domestic services industry. At the same time that the government provided work mechanism for domestic workers, it decided their marginal status.

In May 2009, the Chinese government established an inter-ministerial joint group for the development of family services, which was composed of the Ministry of Social Affairs, the Development and Reform Commission, the ministry of Civil Affairs, the Ministry of Finance, the Ministry of Commerce, the National Federation of Trade Unions, the National Women's Federation and the Central Committee of the Communist Youth League. The government then actively expressed its interest in learning from the good practices and experiences of other Asian countries, strengthening international exchanges and cooperation, and its will, with the support and assistance of the International Labour Office, to improve the domestic workers' legislation, and rights protection. On 5 September 2013, the ILO Domestic Workers' Convention entered into force, an important step for giving basic labour rights to domestic workers. Various domestic workers NGOs studied and discussed this convention, but the Chinese government made no mention of it.

In short, because the law is exclusive to domestic workers, the organization of domestic workers lacks institutional guarantees.

\section{Marketization of domestic service: To train domestic workers in order to compete}

In order to compete, the domestic service company has adopted the training of domestic workers in the position of employer's demands. With the vigorous support of the government, private companies in the domestic sector rapidly increased. There are currently three types of domestic services companies: intermediary companies, affiliate companies and staffed companies. The intermediary type is the most common. These companies provide intermediary services, charge an intermediary's fee, and clients, domestic workers and the intermediary organ have an information service relationship. Staffed companies are also known as service dispatching companies. Here the domestic workers are staff of the domestic services company, which sends them to the homes of clients to provide services. In this case the domestic worker and the domestic services 
company have a labour contract relationship. The government encourages staffed companies, because this implements the requirements of the Labour Contract Law; the domestic worker signs a labour contract with the company. But, in fact, very few are able to become staff dispatched by these company. Affiliate companies are a kind of composite organization. Their operational model is a business management model situated between the intermediary domestic services organizations and the staffed domestic services organization. This kind of company is a market operation cantered on the employer; it provides diversified services and charges different fees based on the varying demands of employers at different economic income levels for domestic service workers. It is an operational model divided off through competition. Market competition and the differentiated demands engendered by social divergence combine to facilitate the diversification of the domestic services industry, where high-end services are favoured because of their high return. Maternity services have become a notably high-end service due to the extreme importance society still places on female child-bearing. Following the traditional gender role division of labour, the intrinsic value of caretaker work continues to maintain the same status in the domestic services industry, manifested in commercialized methods. The consumer model serving the upper class has been popularized in the market branding of domestic services companies. The company Ayi laile ("Aunty's Here") strives to provide the "warmest housekeeper community and housekeeping platform", highlighting the emotional output of the service. ${ }^{6}$

With the increasing use of Internet, new domestic services supply and demand relations are taking shape. Following the designated gender temperament, use of the $\mathrm{O} 2 \mathrm{O}$ (online to offline) method to provide services, i.e., carrying out real-time link-up and real-time matching, has expanded the traditional scope of domestic services. This has given rise to products promoted on the pretext of "the good life" (meihao shenghuo). The Yancheng Good Life Professional House-cleaning Company refers to the professional cleaners in its domestic cleaning project as "home beautifiers". 7 The new type of domestic services company incorporates modern concepts to meet a new type of domestic services demand; in fact, the market energetically creates services demand with mainly female temperament, such as cosmetics, manicures, therapeutic massage, etc. These services were all but non-existent during the planned economy era, but now have been made available, some even offered in-home. These kinds of "lazy woman can also be beautiful" and "58 to Home" beauty services also include all kinds of adornment. Both supply and demand in the domestic services market have become the domains of tech-savvy young people, and a traditional female gender temperament has been produced through the push of consumerism.

This kind of company provides a transaction platform for customers and domestic services companies, and the recruited labourers are self-employment, consciously defining domestic workers as having an equal and mutually beneficial cooperative relationship rather than a labour relationship between employer and employee, the platform provides the information of supply and demand. The companies provide free training to young employees, and also provide the relevant tools of production such as gloves, cleaning cloths, detergent and the work uniforms with the "58 to Home" ${ }^{8}$ brand and logo printed on them. In terms of remuneration, the enterprise sets a minimum number of hours per month, and as long as the employees fulfil the base hours, they will 
receive a competitive salary from the company. The larger the number of orders, and the higher the customer evaluations, the more additional bonus payments they will receive. But the company does not provide staff with medical insurance, unemployment insurance, retirement benefits or other such social insurance. Forging a "free and self-initiating" employment space has become an important slogan for Internet domestic services companies that cater to the pursuits of modern young people.

The Organization of Domestic Workers: Labour NGOs and domestic worker unions Domestic workers have their own internal needs to organizing. While the state and the market have actively constructed the domestic sector without workers' interests, their female and migrant worker identities intensify their marginalization and secondary position. In order to be able to continue their work and life, they need basic emotional support and solidarity, they build mutual aid organizations in their daily life. Workers have used their own strength to form interest communities. Most domestic workers rely on support networks made of people from their places of origin, and very seldom take part in formal organized activity. Using hometown connections to obtain domestic service work is an important way for domestic workers to access work opportunities. The mainly region-based relationships are characterized by a low degree of organization. But dynamic society has also given rise to some domestic worker organizations. We observed two types of domestic worker organizations: labour NGOs and domestic workers unions. The organization of domestic workers demonstrates the inherent cohesive force of the female gender identity.

The marketization process of domestic workers is competitive. Intermediary companies have constructed the urban's dominant culture through pursuing a better lifestyle and weakened the cultural status of domestic workers. They are still fragmented and flexible labours.

\section{Domestic worker groups in mutual aid-type labour NGOs}

Two case studies illustrate domestic worker groups in mutual aid-type labour NGOs. Dagongmei zhi jia (Home of the Migrant Working Girl) was created in 1996 by the magazine Rural Woman (Nongjianü), a subsidiary of China Women's News (Zhongguo funü bao). ${ }^{9}$ Its main leaders and organizers are educated women, with female migrant workers (dagongmei) gradually taking on self-management. Dogongmei zhi jia has a Domestic Service Workers' Mutual Aid Committee that provides a platform for equal exchanges and experience sharing. This mutual aid committee has monthly activities that include recreation, psychological counselling, professional training, etc. Most of the participants are female migrant labourers with a certain level of education and a need to get something off their chests. Here they satisfy their need to find friends, learn computer skills, settle disputes, etc. The Domestic Service Workers' Mutual Aid Committee also publishes material that expresses the thoughts of domestic workers, such as Xiaoxia Comes to Beijing to Do Domestic Work, and We Are the Same, and also has related training materials such as Employers' Handbook, and research-type documents such as Domestic Worker Bulletin, Perspectives on Domestic Work, etc. Domestic workers organized the Dandelion Opera Troupe, the members of which are domestic workers from all over China who have come to Beijing to work. Claiming the 
ordinariness, purity and tenaciousness of the little dandelions that fill the fields in spring, they display their lives in self-written, self-directed and self-performed plays.

A second example is the Fuping Domestic Services Centre founded in 2002 by prominent intellectuals and the Fuping School of Home Economics. In 2005, the centre established the Fuping Domestic Workers' Mutual Aid Committee, holding activities once a month. Up to the end of 2014, the mutual aid committee had recorded 30,000 participations by domestic workers. The head of the Fuping Domestic Workers' Mutual Aid Committee, Wang Li, was once an activist at Dagongmei zhi jia. While working in Beijing in 2000, Wang Li took part in activities at Dagongmei zhi jia, where she learned how to type on a computer. In 2003. Wang Li participated in the three-month initial semester of training for high-level domestic services workers at the Rural Women's School. She says:

"At a seminar on domestic workers' rights in 2003, I became acquainted with someone from the Fuping public interest organization, and she told me that my speech, 'How to be a good nanny', had left a deep impression on her, and that I should come to Fuping. I said I had no education, but she said, 'It doesn't matter, just come!' In 2005, I went through more than a year of training at Fuping and suggested establishing a mutual aid committee for female domestic workers. That's because one time I ran into someone who had finished the course and was working, and I asked her how she spent her two days off each week. She said, 'I take a bottle of water and three steamed buns and sit at the entrance of my client's home from when the sun rises until the sun sets, and when I finish my water and my buns, I go back to my client's home'. At that time I thought, Fuping trains more than 3,000 domestic workers every year, but after they're trained, we could also set up a mutual aid committee. So I wrote up my idea for setting up a mutual aid committee. The committee was set up, and we organized domestic workers to visit Tiananmen Square and to do volunteer work. In March 2012, we set up an arts group for domestic workers. They joined in writing their own stories and plays and performances... Dagongmei zhi jia gave me the confidence and opportunity to be the person I am today. So I'm working hard to use my professional abilities to serve even more of my sisters!" ${ }^{\text {10 }}$

The organization of domestic workers can be self-replicating under certain conditions. Although these committees and activities can't change the marginalized status of domestic workers, they create a feeling of home and form a mutual support community for these women in an alien city. The domestic worker identity - dignified, valuable work that serves the needs of families - is not only experiential but also political. The organization of domestic workers in itself has the power to resist domestic workers becoming vassalized, privatized and marginalized.

Chinese labour NGOs, still in the germination stage, play an important role in accumulating social capital for workers, forming emotional bonds and fighting unfairness (Zhu 2008). But there is also a viewpoint that holds that most labour NGOs have fallen into the dual trap of commercialization and government co-opting, and have been unable to empower workers, but rather have become an anti-solidarity machine that undermines workers power. Under the current political system and commercialization, labour NGOs can only function within the government's prescribed boundaries, 
publicizing workers' narrow labour rights, and these circumstances are not conducive to the re-emergence of China's workers class (Lee and Shen 2011). Research has found that labour NGOs in which domestic workers participate were not initially set up on the foundation of class politics, but rather arose from a sense of morality and justice. Labour NGOs hope that by taking part in activities, domestic workers can find a feeling of home in a strange city. Gender identity leads domestic workers to engage in venting-type exchanges over their dissatisfaction with their clients and the hardship of their lives, leading domestic workers to form their own social support networks.

\section{Domestic worker unions}

Traditional labour union theory holds that the informal employed are inherently unorganized and cannot establish unions within the organization, and that this characteristic deprives them of the power of collective negotiation. Viewed from class theory, the inability to form class consciousness and class solidarity is the disadvantage of their working conditions, and an important reason for the atomization of their social status. But our research finds that there are many forces within the domestic sector, and that there have been attempts to establish unions. Although successes have been few, this effort at unionizing is very valuable.

For instance, the Beijing Rural Women's Cultural Development Centre has been striving since its establishment in 1995 to defend the rights and interests of working women. ${ }^{11}$ After establishing a Domestic Workers' Mutual Aid Committee in 2004, it has striven through lawful means to protect the interests of domestic workers in the hopes of establishing a labour union. According to the requirements of China's Trade Union Law, unions have to be "organized in the employing unit", and since Dagongmei zhi jia is not an employing unit, it cannot establish a trade union. In 2010, the Rural Women's Cultural Development Centre established the Dongcheng In-home Elderly Services Centre, offering in-home elder care, maternity services, infant care and housekeeping services. In December 2011, the services centre established a Domestic Workers' Union through the effort of labour NGOs. When the union was established it had 34 members, of whom 26 worked in the service centre, and the other eight of whom were domestic workers in other companies. That union has at times reached more than 100 members, but because of the high mobility of domestic workers, the number of union members has been unstable. This union mainly takes on the responsibility of training and organizing activities for domestic workers. But against the background of the state monitoring the funding of community organizations in 2015, it has been difficult for this union to develop.

Beijing Huaxia Zhongqing Domestic Services Co. Ltd. established a trade union in July 2009, mainly for training purposes. In 2011, this union became the first in the domestic services industry to receive an ACFTU (All China Federation of Trade Unions) Workers Vanguard number. The company was established at the end of 1998 as a nation-wide chain, and its headquarters and branches all established trade unions that directly elect their union presidents. The main reason the company established the union was that its supervisory body is the Youth League Central Committee, which gives it a semi-official flavour.

Trade unions are sometimes established at the municipality level. In September 2004, the city of Xi'an, Shaanxi Province, established the Xi'an Domestic Workers Trade, 
subordinate to the Xi'an Municipal Federation of Trade Unions Re-employment Services Centre for Laid-off Workers (later renamed Domestic Services Centre). The members of the union were female laid-off workers engaged in domestic service work. This is the only municipal-level trade union in the entire country. Around the year 2000, the Xi'an Municipal Federation of Trade Unions Re-employment Services Centre for Laid-off Workers mobilized and arranged domestic service jobs for more than 12,000 female laid-off workers. These workers had experience working in state-owned enterprises, and they demanded establishing their own union organizations in order to settle potential labour disputes between domestic workers and their employers. After it was established, the union set up an arbitration commission to carry out mediation on related issues. As a trade union, it implemented a tripartite negotiation mechanism consisting of the municipal-level domestic services workers' union plus domestic workers associations plus client representatives, and on the foundation of collective negotiations tabled the "Domestic Services Regulations." The survey found that the domestic services union's participation rate was limited, with 182 members in 2004, all of them laid-off domestic service workers over 40 , of whom about $70 \%$ were the heads of one-parent families. The largest number of members the union ever had was around 1,500. In 2012, the Xi'an Domestic Workers Union launched a related legal publicity campaign and hosted a legal workshop for domestic workers to discuss the Domestic Workers' Part-time Service Contract (Trial Edition). ${ }^{12}$

The president of that trade union, Wang Wei, had taken up domestic work after being laid off from an SOE in 2002. In 2003, she participated in activities organized by the Domestic Workers Committee of the Northwest University Women's Development and Rights Research Centre. After taking part in training to "empower marginalized female labour leaders," she established the Laid-off Domestic Workers Committee, which domestic workers refer to as the "grassroots committee." It aimed at achieving solidarity and the right to organize and fighting to obtain social resources for female workers, and to build the capacity of marginalized workers to adapt to the market, master professional skills and engage in labour negotiations and agreements. Through the committee's activities, Wang became acquainted with many domestic workers suffering the same hardships as herself:

"Some of the domestic workers were in an even worse situation than I was.

They were all laid off, and when the weekend arrived they'd gather together discussing shared topics, and as soon as they'd start talking they'd cry, all of them together."13

It was this mutual outpouring of emotion and mutual support, Wang Wei said: "With a trade union we had backing; the union was our own organization." As president of the Xi'an Domestic Workers Union, Wang Wei has another identity as a domestic services instructor at the Xi'an Municipal Federation of Trade Unions. During the working week she is a trainer, and during her off hours on the weekend she does trade union work. Through her effort, the union opened an independent office in October 2011. A survey of the union in 2016 found that it was having great difficulty developing, and lack of financial resources was threatening its sustainability.

The establishment of the Domestic Workers Union was an effort by multiple forces using lawful means to establish self-organization by domestic workers. But under the 
framework of state corporatism, domestic workers' unions have not yet been effectively channelled into the labour union apparatus; the marginalized status of domestic workers has decided the marginalized nature of their union organizations. In the process of organizing domestic workers, female identity causes their organizing activities to have gendered characteristics; they share mutual aid and culture, and use solidarity to promote the capacity of domestic workers in market negotiations. In short, the degree of organization of domestic workers is very low. The strategy of organizing domestic workers is to establish their own network to mutual aids and support the resistance in daily life. It is important to improve the ability and give the emotional support, although it is difficult for them to obtain legal rights through unity under the existing political framework, market competition and urban mainstream culture.

\section{Conclusion and discussion}

Female workers in domestic sector are the hidden side of the Chinese market economy. The current 25 million female workers non only contribute to the stable reproduction of the population of urban families population, they also contribute to China's rapid economic growth. These hidden and neglected workers are at the basis of China's market-oriented production regime. The reproduction system of families, the gendered division of domestic labour, and urban inequalities are the pillars of the China gendered system of production. Women are the producers of most of the work for demographic reproduction. Because the work is produced in the private space, its value is less than the value of male labour, produced in the public space. The gender labour regime is the backbone of China's economic growth.

First, contracting domestic work is apparently a family decision made on a market, but it is in fact the consequence of the state's withdrawal from population reproduction. As Wallerstein points out, "home is a world economic system" but the home may be the most neglected system of the world capitalist economy (Wallerstein 2003). When the urban family can not rely any longer on the danwei for the provision of meals, kindergarden and other benefits, families have to assume the responsibility of population reproduction by themselves. The population aging and the "second child" policy have strengthened the function of population reproduction and sharply increased the amount of household labour. Patriarchism has contributed to the legitimacy of the family revival; the traditional heterosexual family system has been strengthened; the market transition has restructured the roles of the state, the family, the women and the market.

Second, after the socialist era, the prospects for urban women to participate in public affairs and to be fully employed is limited because of their family responsibilities. The reproduction of the family population makes necessary a gender division of work within the family. The gender division has been strengthened, on the basis of the traditional gender stereotyped social roles. Housewives either give up their career or seek the help of a family or home worker. Therefore, the demand for domestic workers reflects the new characteristics of China's polarized society, The emergence of urban middle class housewives and professional women explain the needs for marketized domestic labour. Women have to achieve a professional life as well as be good mothers. Behind each working women, they may have a domestic worker.

Third, some of studies have argued that China has evolved from a danwei society to a society of class struggle, and to finally a society based on individual voluntary 
contracts among the various actors, as if the social groups, the government, the media, the intellectual groups were involved in positive interactions. However, studies show that the degree of organization of domestic workers is worrying. Female domestic workers rarely participate in trade union and NGO activities. The lack of organizing determines the marginalization and fragmentation of domestic workers. The fact that domestic workers workplaces are dispersed and often change make collective action difficult. The resistance of the domestic workers is mostly an individual behaviour; just like personal service industry employees in Western countries, they sometimes form class alliance with larger labor resistance movements. The existing NGO groups of domestic workers are more based on gender identity and migrant identity to unite for protecting their own interests and give the emotional supports each other, domestic workers are actively building their own social support network. The organizations of domestic workers are both struggling for better mutual support and better existence. In a gendered society, gender identity has become an important resource for workers unity. At the same time, knowledgeable intellectuals, feminists who care about the economy and advocates of the legal protection of labour interests ally with domestic workers. Together with small groups of domestic workers, they take initiatives on the Internet, take part in streets actions, television programs, publish books and brochures to explain the cultural and economic values of domestic workers, in order to resist to the commercialization and the fragmentation of labourers induced by the neoliberal ideology.

\section{Endnotes}

${ }^{1}$ Zhang Wenfan, "Wenzhong qiujin, chuangxin fazhan dazao juyou Zhongguo tese, Zhongguo qizhi, you suyang de jiating fuwu duiwu" (Progress in stability, innovative development; forging a domestic service contingent with Chinese characteristics, Chinese temperament and attainment), work report presented on August 21, 2012, at the enlarged conference of the fourth congress of the third board of directors of the Chinese Domestic Services Industry Association.

${ }^{2}$ Regarding discussion of women returning to the home, see: Zheng Yefu, "Nannü pingdeng de shehuixue sikao" (Sociological reflections on male-female equality), Shehuixue yanjiu, No. 2, 1994; Li Yinhe, "Nüren huijia wenti zhi wojian" (My views on the issue of women returning to the home), Shehuixue yanjiu, No. 6, 2994; Tan Shen, "Shui shi xuanze de zhuti" (Who is the selecting principal), Shehuixue yanjiu, No. 6, 1994; Zhao Huizhu, "Huijia' shi-fou shi nüxing fazhan de heli moshi” (Is "returning home" a legitimate model for women's development?), Shehuixue yanjiu, No. 3, 1995.

${ }^{3}$ See website of the Sanba jiazheng fuwu zhongxin: http://www.bjsanbajz.com.

${ }^{4}$ See website of the Beijing 38 Homemaking Service Center: http://www.bjsanbajz. com/web/about/about.asp.

${ }^{5}$ While attending a conference related to domestic labor convened by the Ministry of Human Resources and Social Security, the author learned that the relevant leaders in 2000 handed down a memo requiring the Ministry of Commerce and Ministry of Human Resources and Social Security to manage the domestic sector

${ }^{6}$ See the website: www.ayilaile.com.

${ }^{7}$ See the website: www.jsgoodlife.cn.

${ }^{8} 58$ pronunciation in Chinese is equivalent to my home.

${ }^{9}$ See: weibo.com/1197557374 
${ }^{10}$ Speach given on May 21st 2016, on the 20th anniversary of the foundation of Dagongmei zhi jia organisation.

${ }^{11}$ For more on the Rural Women's Cultural Development Center, see Tamara Jack, Rural Women in Urban China: Gender, Migration, and Social Change, M.E. Sharpe, Armonk, New York and London, 2006, Chinese edition translated by Wu Xiaoying, Nanjing, Jiangsu renmin chubanshe, 2006.

${ }^{12}$ For more on the Xi'an Domestic Workers' Union, see Guo Huimin, “Jiazheng nügong de shenfen yu tuanjiequan zhengzhi - Yige jiazheng gonghui nügong qunqi de ge'an yanjiu" (The identity of female domestic workers and their political union rights: A case study of a female domestic workers' union), op. cit.

${ }^{13}$ May 21st 2016. See note 44.

Abbreviations

ACFTU: All China Federation of Trade Union; GDP: Gross domestic product; NGO: Non governemental organization; O2O: Online to offline; PRC: People's Republic of China; SOEs: State-owned enterprises

\section{Acknowledgements}

Only Tong Xin contributed towards the original article in Chinese. The text was translated into English by Stacy

Mosher and Gilles Guiheux.

\section{Funding}

This research was made possible by funding from 2011 China National Social Science Foundation major program "Legal Structure Research in Harmonious Labor Relations Coordinating Mechanism" (11\&ZD031) subtopic "Research in Dispatched Labor."

\section{Availability of data and materials}

Original data are interviews that the author will not disclose to the public. Contact author for data requests.

\section{Authors' contributions}

This article is the sole work of Prof. Tong Xin. The author read and approved the final manuscript.

\section{Competing interests}

The author declares that he/she has no competing interests.

\section{Publisher's Note}

Springer Nature remains neutral with regard to jurisdictional claims in published maps and institutional affiliations.

Received: 8 May 2018 Accepted: 14 October 2018

Published online: 06 November 2018

\section{References}

Ehrenreich, Barbara, and Arlie Russell Hochschild, eds. 2003. Global Woman: Nannies, Maids, and Sex Workers in the New Economy. New York: Metroplitan Books.

Fang Ying, "Sichang zhuanxing yu Zhongguo chengshi xingbie zhixu fenhua" (Market transition and the division of the gender order in China's cities), Jianxi shehui kexue. 1, 2008.

Feng, Xiaoshuang. 2004. "Zhuanxing shehui zhong de baomu yu guzhu guanxi" (Housekeeper-employer relations in transitional society). In Zhuanxing shehui zhong de Zhongguo funü (Chinese women in transitional society), ed. Meng Xianfan. Beijing: Zhongguo shehui kexue shubanshe.

Guo Huimin, "Jiazheng nügong de shenfen yu tuanjiequan zhengzhi - Yige jiazheng gonghui nügong qunqi de ge'an yanjiu" (The identity of female domestic workers and their political union rights: A case study of a female domestic workers' union), Funü yanjiu luncong. 6, 2009.

Han Huimin, "Jiazheng fuwuyuan xingsaorao wenti de zhiye tedian" (The occupational characteristics of sexual harassment of domestic service workers), Funü yanjiu luncong. 8, 2006.

He Mingjie, "Laodong yu jiemei fenhua -'Heji' shengchanti ge'an yanjiu" Labor process and the differentiation of sisterhood: A case study on female migrants in China, Shehuixue yanjiu. 2, 2009.

Hochschild, Arlie Russell. 1989. The Second Shift: Working Parents and the Revolution at Home. New York: Avon Books. Hochschild, Arlie Russell. 2000. The Nanny Chain. The American Prospect 11: 32-36.

Lan, Pei-Chia. 2006. Global Cinderellas: Migrant Domestics and Newly Rich Employers in Taiwan. Durham N.C: Duke University Press. Lee, Ching-kwan. 1998. Gender and the Social China Miracle - Two Worlds of Factory Women. Berkeley: University of California Press.

Lee, Ching-Kwan, and Yuan Shen. 2011. The Anti-Solidarity Machine? Labor Nongovernmental Organizations in China. In From Iron Rice Bowl to Informalization, ed. S. Kuruvilla, Lee Ching-Kwan, and M.E. Gallagher, 173. Ithaca: Cornell University Press.

Ma, Dan. 2012. "Siren shenghuo de shangpin: Beijingshi zhujia jiazhenggong de laodong duocheng de yanjiu" (A commodity of private life: Research in the labor process of live-in domestic workers in Beijing). Peking University: PhD thesis.

Milkman Ruth, L.A. Story: Immigrant Workers and the Future of the U.S. Labor Movement, Russell Sage Foundation, 2006. 
Milkman, Ruth, Joshua Bloom, and Victor Narro, eds. 2010. Working for Justice: The L.A. Model of Organizing and Advocacy. Ithaca, NY: Cornell University Press.

Ministry of Commerce, Domestic Services Industry Development Report, 2015, http://www.fdi.gov.cn/1800000121_35_521_0_7.html. Ong, Aihwa. 1991. The Gender and Labor Politics of Postmodernity. Annual Review of Anthropology 20: 279-309.

Pun, Ngai. 2011. Zhongguo Nügong - Xinxing dagongzhe zhuti de xingcheng (Chinese women workers: The rise of a new type of worker). Beijing: Jiuzhou chubanshe.

Salazar, Parrenas Rachel. 2001. Servants of Globalization: Women, Migration and Domestic Work. Stanford, CA: Stanford University Press.

Song Shaopeng, "'Xingbie' yihuo 'xingbie yixhi'?: Nüxing shefu lilun jieshi kuangjia tanxi" ("Gender or "gendered system"?: Analysis on the theoretical and interpretive frameworks of women's involvement in corruption"), Funü yanjiu luncong. 3, 2015.

Sun, Wanning. 2009. Maid in China: Media, Morality and The Cultural Politics of Boundaries. London: Routledge.

Tian, Yipeng, and Peiyao Li. 2014. "Jihua shiqi guoqi 'fu'aizhuyi' de jairenshi - Yi danwei zinü jiuye zhengce wei zhongxin" (A re-acknowledgement of the paternalism of planned economy-period state-owned enterprises - Employment policy centered on Dan weit sons and daughters). Jianghai xuekan (3).

Tong, Xin. 2017. Care labour and gendered labour regime in China. Jiangsu Social Science (3).

Wallerstein, Immanuel. 2003. The Essence of Wallerstein. Nanjing: Nanjing daxue chubanshe.

Yan, Hairong. 2010. Zhishi fenzi fudan yu jiawu laodong: laoxin yu laoli, xingbie yu jieji zhiyi. Kaifang shidai 6: 103-120.

Zhou Jianxin, Zhou Daming, "Baomu de qunti tezheng yanjiu - Zhongguo dongnan yanhai sangong dianxing ge'al yanjiu zhi yi" (Research on the group characteristics of housekeepers - Research on a classic case of part-time labor on China's southeast coast, part 1), in Xinan Minzu Daxue bao (Renwen sheke ban) (Journal of Southwest University for Nationalities [Humanities and social sciences edition]) 3, 2007

Zhu, Jiangang. 2008. "Dagongzhe shehui kongjian de shengchan - Panyu dagongzhe wenhua fuwubu de ge'an yanjiu" (The production of social space for workers - the Panyu Workers' Cultural Services Bureau as a case study). In Zhongguo zhidu biangian de anli yanjiu (Case studies in China's changing system), (Vol. 6, Guangdong), Zhongguo caizheng jingji chubanshe, ed. Zhang Shuguang.

\section{Submit your manuscript to a SpringerOpen ${ }^{\circ}$ journal and benefit from:}

- Convenient online submission

- Rigorous peer review

- Open access: articles freely available online

- High visibility within the field

- Retaining the copyright to your article

Submit your next manuscript at $\boldsymbol{\nabla}$ springeropen.com 